\title{
Online Resourcing in Maritime English Teaching: The Teachers' Challenges
}

\author{
Purnama NF Lumban Batu, Sakilah Bewafa, Wida Cahyaningrum \\ Sekolah Tinggi Ilmu Pelayaran \\ Jl. Marunda Makmur Cilincing Jakarta Utara \\ e-mail: nancy.lumbanbatu@gmail.com
}

\begin{abstract}
Due to the Covid-19 pandemic, a sudden shift of learning model to online system has brought new challenges to the teachers. They are obliged to adapt and conduct new classroom practices to ensure an effective teaching and learning process is carried out. These new teaching practices are applied in the whole teaching process, from planning to evaluating processes. These include material resourcing, material development, material delivery, and assessment. This paper presents a micro-study focusing on how Maritime English (ME) teachers in Jakarta adapt to the online teaching and learning process in material resourcing and delivering processes. The data were collected through an online questionnaire distributed to twenty-one ME Teachers at high school and higher education levels. The results show that the teachers find it challenging to adapt to online learning and tried their utmost by using whatever resources they have in their hands. However, there is a lack of consideration in using proper online resources to achieve the learning objectives.
\end{abstract}

Keywords: Covid-19, Online, Material, Resources, Maritime English

\section{Introduction}

In teaching English, teachers often face challenges that insist them to create innovations for education, starting from content to be covered, pedagogical strategies employed in classrooms, as well as the hardware and software used to deliver programs. Due to the Covid-19 pandemic, a sudden shift of learning model to online system has brought new challenges to the teachers. They are obliged to adapt and conduct new classroom practices to ensure an effective teaching and learning process is carried out. These new teaching practices are applied in the whole teaching process, from planning to evaluating processes. These include material resourcing, material development, material delivery, and assessment.

Based on the background above, the literature review highlights the role of CLIL in $\mathrm{ME}$, factor influences planning, delivering, and evaluating process in online teaching and learning, principles in carrying out online TL, and ME in Indonesia context. "CLIL is a dual-focused educational approach in which an additional language is used to learn and teach of both content and language." (EuroCLIC 1994). It is a way of teaching by integrating content learning and language learning. Students learn the language they need to study at the same time as they learn the subject. CLIL underlines teaching content and language. In the context of teaching Maritime English, it goes in line. The teacher/ instructor needs to decide various material resourcing that underlines both Maritime English content (knowledge) and English (skills and language features).

This paper is presented in The $4^{\text {th }}$ International Conference on Maritime Education and Training

October $8^{\text {th }}$, 2020, Makassar, Indonesia 
Some studies explain some essential considerations regarding the factors that influence planning, delivering, and evaluating processes in online teaching and learning. At the planning stage, it is essential to consider students learning styles in both educational and instructional processes as it provides the best way of learning. Considering students' learning styles also plays a role in making students actively participate in learning [8]. Online teaching and learning require students to be more active, independent and learn at their own pace [6][7]. Considering student's learning styles is essential during the planning process. In general, learning styles consist of auditory, visual, and kinesthetic [5][11]. These studies emphasize that in planning to evaluate online teaching and learning, it is essential to consider students' learning styles. It affects students' participation, and therefore their success in learning. Learning styles can be inserted into material planning by choosing carefully online material resources that match each learning style, such as websites and other online platforms.

In determining which online platforms to use, teachers need to consider principles in online teaching and learning process as mentioned by (Pelz, 2003): let the students do most of the work (actively involve), interactivity (within the students and with the instructor/teacher), and strive for presence: social presence (attendance), cognitive presence (discussion on the topic), or teaching presence (instruction) [12]. Implementing those principles is done by considering appropriate platforms for implementing online teaching and learning, especially in the delivery stage. In other words, online platforms that are used need to characterize those principles, especially for online teaching delivery process.

Furthermore, several researchers found out some facts regarding Maritime English in the Indonesian context. Maritime English teachers with a maritime background are not acceptable in general English, lack knowledge about systematical English studies, and are considered poor in ESP's teaching method. Most Maritime English teachers with a General English background are not familiar with maritime English and maritime subjects [13]. Meanwhile, students described the ideal teacher as a person who is a friendly, young, enthusiastic, creative, and humorous person whose gender is not essential. Students expect their teacher to be a native speaker of Indonesian but fluent in English, someone who likes to play educational games and teaches maritime context effectively using real-life situations to explain language items [2]. However, there is a lack of and scarcity of the Maritime English learning materials, the insufficiency, and the irrelevance of the existing Maritime English materials for the nautical students [4].

On the other hand, there was a high demand for materials that could prepare them to have good communication skills. Most students assumed that the four language skills (listening, speaking, reading, and writing) in English are crucial. However, they placed productive skills (writing and speaking) as their highest priority [1].

Through this micro-study, the researchers aimed to reveal the condition of online teaching and learning process of ME teachers as well as whether or not they can adapt and adapt to the sudden shift. More specifically, this study aimed to answer how the Maritime English (ME) teachers in Jakarta adapt to the online teaching and learning process in material resourcing and delivering processes. This study is expected to deliver a clearer picture of how the ME teachers adapt to the sudden shifts in teaching English as a foreign language under ME's umbrella term. It is then expected that this study can contribute to building awareness among teachers and the institutions on what is happening with the teachers and the effects on their teaching practices. The findings of this study will have

This paper is presented in The $4^{\text {th }}$ International Conference on Maritime Education and Training 210 
impacts on the improvement in setting up the learning objectives and the students' learning achievement.

\section{Method}

This microstudy is a descriptive qualitative study. To collect the data, the researchers distributed a questionnaire to $35 \mathrm{ME}$ teachers, though only 21 of them completed and submitted the questionnaire. The data were then tabulated and categorized to describe the existing practice of each of the participants. From those 21 responses, some findings regarding the material resourcing and delivery processes are highlighted in the discussion part.

\section{Results And Discussion}

\subsection{Material Resourcing}

3. Sumber materi daring manakah yang pernah Anda gunakan? (jawaban bisa lebih

21 responses

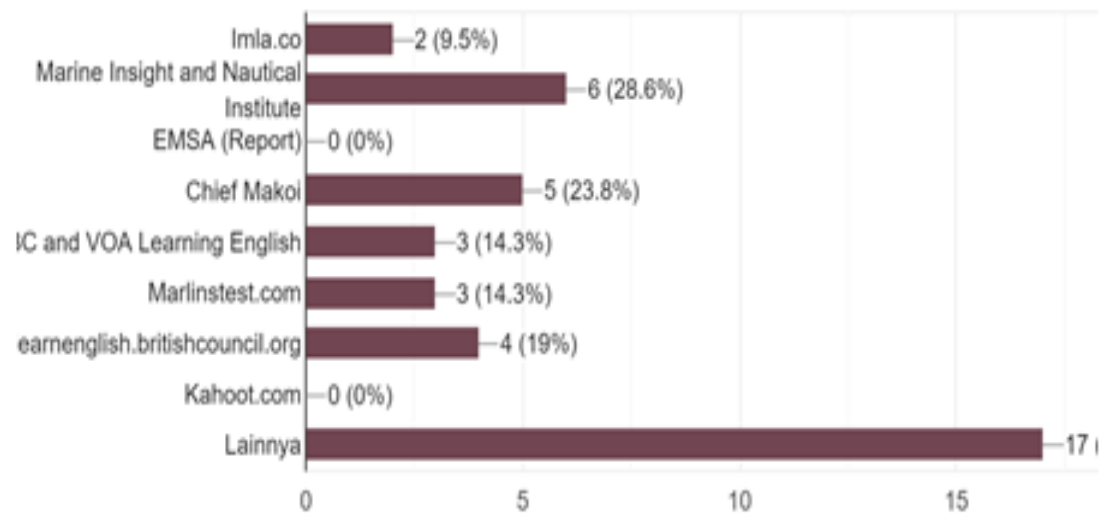

Figure 1. Primary sources of learning materials (Authors' data)

The chart above shows some online resources considered proper as they fairly characterize various students' learning styles. Based on the chart, regarding the online material resourcing, which is a part of material planning, most ME teachers $(81 \%)$ rely on random resources they can find through the search engines rather than determine the types of materials that match the learning styles. Further, very few ME teachers seem to do the material resourcing by considering the proper online resources related explicitly to maritime studies.

\subsection{Delivery Processes}

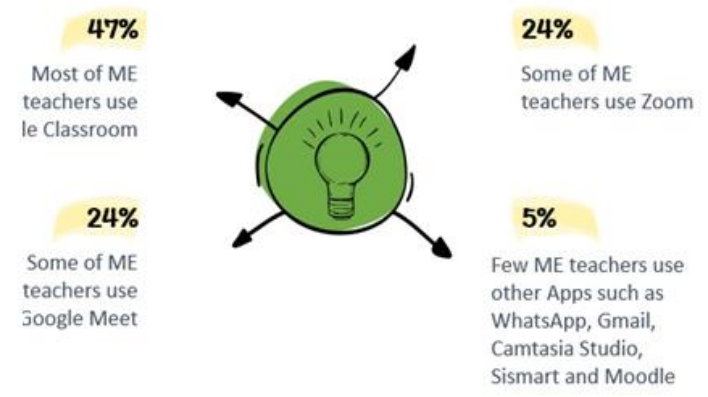

Figure 2. Types of online platforms used (Authors' data)

This paper is presented in The $4^{\text {th }}$ International Conference on Maritime Education and Training 
The diagram above presents ME teachers' online platforms' preferences for delivery processes during online teaching and learning. Online platforms such as Zoom and Google Meet are considered as the most appropriate platforms for implementing online teaching and learning as they meet the requirements of online teaching and learning principles, especially for the interactivity and cognitive presence. Unfortunately, less than half of ME teachers use them for delivery processes. Though the teaching and learning process has shifted from offline to online, teachers should try their best to make sure the online teaching and learning goals can be achieved as close to offline teaching and learning as possible. Teachers are challenged to build on core principles from their face-to-face courses, be realistic about the amount of content they can cover online, and then choose tools that support these goals (McQuirter, 2020).

\section{Conclusion}

Based on the discussion, this study concludes that the teachers find it challenging to adapt to online learning and tried their utmost by using whatever resources they have in their hands. Most of the respondents use Google Classroom for their online platforms. They find it most convenient to adapt. Further, most of the respondents use other online sources. Unfortunately, these were not identified yet in this microstudy. However, there is a lack of consideration in using proper online resources to achieve the learning objectives.

This study also addresses some limitations and suggestions regarding the data and samples of the study. The data covers only material resourcing listed in the given options. Further study needs to outline typical material resourcing ME teachers use and factors affecting teachers' online teaching and learning. Data should be triangulated with sets of structured or semi-structured interviews with the participants. More participants should be involved to have more representing results.

\section{References}

[1] Aeni, N., Jabu, B., Rahman, M., Ismail, H., \& Bin-Tahir, S. (2018). The Students' Needs in Maritime English Class at Ami Aipi Makassar, Indonesia.

[2] Anggraini, L. P., Ernis, E., \& Jelenska, J. M. (2020). Students' Perceptions towards Ideal Maritime English Teacher. Biormatika : Jurnal Ilmiah Fakultas Keguruan Dan Ilmu Pendidikan, 6(02), 29-35. https://doi.org/10.35569/biormatika.v6i02.796

[3] Akram Awla, H. (2014). Learning Styles and Their Relation to Teaching Styles. International Journal Of Language And Linguistics, 2(3), 241. https://doi.org/10.11648/j.ijll.20140203.23

[4] Dirgeyasa, I. (2018). The Need Analysis of Maritime English Learning Materials for Nautical Students of Maritime Academy in Indonesia Based on STCW'2010 Curriculum. English Language Teaching, 11(9), 41. https://doi.org/10.5539/elt.v11n9p41

[5] Dörnyei, Z. (2005). The Psychology of the Language Learner: Individual Differences in Second Language Acquisition. Lawrence Erlbaum Associates Publishers.

[6] Ghirardini, B. (2011). E-learning methodologies - A guide for designing and Retrieved from http://www.fao.org/3/i2516e/i2516e00.pdf

[7] Hill, C. (Ed.). (2015, 10 February). 10 Principles of effective online Teaching: Best Practices in Distance Education (Rep.). Retrieved https://www.facultyfocus.com/wp-content/uploads/2015/02/10-Principles-ofEffective-on-line-Teaching.pdf

This paper is presented in The $4^{\text {th }}$ International Conference on Maritime Education and Training 
[8] Kazu, I. Y. (2009). The Effect of Learning Styles on Education and the Teaching Process. Journal of Social Sciences, 5(2), 85-94. DOI:10.3844/jssp.2009.85.94

[9] McQuirter, Ruth. (2020). Lessons on Change: Shifting to online Learning During COVID-19. A journal of educational research and practice 2020 Vol. 29 (2) 47-51. https://journals.library.brocku.ca/brocked/index.php/home/article/view/840

[10] Montalto, S. A., Walter, L., Theodorou, M., \& Chrysanthou, K. (n.d.). The CLIL Guidebook - languages.dk. Retrieved from https://www.languages.dk/archive/clil4u/book/CLIL\%20Book\%20En.pdf

[11] Oxford, R. (2001). Language Learning Styles and Strategies. In M. Celce-Murcia (Ed.), Teaching English as a Second or Foreign Language. Boston, MA: Heinle and Heinle.

[12] Pelz, Bill. (2003). (My) Three Principles Of Effective online Pedagogy, Journal of Asynchronous Learning Networks, Volume 8, Issue 3: June 2004.

[13] Puspitasari, L., Lumban Batu, P., Kusumaningrum, S., \& Wulandari, R. (2020). Maritime English Teachers in Indonesia. Proceedings Of The 1St International Conference On Management, Business, Applied Science, Engineering And Sustainability Development, ICMASES 2019, 9-10 February 2019, Malang, Indonesia. https://doi.org/10.4108/eai.3-8-2019.2290737 